\title{
The Netherlands Colonial Hegemony and Incorporated Islamic Matrimonial System: Lesson Learned From Dutch Hegemony System
}

\author{
Entol Zaenal Muttaqin ${ }^{1}$, Iin Ratna Sumirat ${ }^{2}$ \\ \{zaenal.muttaqin@uinbanten.ac.id ${ }^{1}$, iinratnasumirat69@yahoo.com² $\}$ \\ ${ }^{1,2}$ Universitas Islam Negeri Sultan Maulana Hasanuddin Banten, Indonesia
}

\begin{abstract}
The growth of Islamic matrimonial system in the present Indonesia was originally formulated in the $19^{\text {th }}$ century of the Netherlands colonialism. There are several discourses among Dutch scholars in establishing an applicable law system, and finally the colonial government enacted a new regulation focused on marriage system. The continuity of this social institution derived from the customary hegemony applied by Dutch. Provoked by several scholars the new constitution in 1854 was approved. In that, the Islamic matrimonial system was assimilated into Adat law and therefore the Islamic marriage system was allowed to be practiced in its own way. Nevertheless, this Islamic matrimonial system was formed as a form of colonial hegemony. Accordingly, this paper is intended to describe the development of marriage system in the Netherlands East Indies, and further descriptions will go to the Islamic matrimonial system and its development, and how it survived until post Indonesian colonialism.
\end{abstract}

Keyword: Islamic matrimonial, Netherlands colonialism, Law of Politics

\section{Introduction}

What could be seen in Indonesia as a sovereign country in South East Asia nowadays is straightly come up from the longest and complicated history of its former name Netherlands East Indies[1] (Nederland Oost Indië) when it still occupied and ruled by The Netherlands for nearly 350 years since VOC (Verenigde Oost- Indische Compagnie) landed in Java as it was sent by the merchant company association in Amsterdam and ruled there in the seventeenth century.[2] In the first place, VOC as the biggest company association in The Netherlands had no direct intention to established such a big colony and empire, yet as the vast growth of its influences and power VOC began to set up a principle of law in order to deal with many cases that occurred.

In the first period of this settlement, however, the Netherlands represented by VOC had not have any legitimate power to rule the entire archipelago, yet they began to grasp the variety of law existed in East Indies (recently Indonesia) so that we can divide it into two periods of acquisition as merchant adventurer and merchant prince. In the first span they arranged themselves as an observer of local customs and law to be learned, because they had themselves amazed by the large variety of customs and law in every region, the second phase was the period of reforming the strong position and in this case, to some extent, built their hegemony through the monopoly trading by all means such as securing the potential land, opening a relationship with indigenous leaders, and so forth.[3]

Unlike the other nations that occupy other country perhaps, the Netherlands has its own 
particular policy to establish its power and hegemony by all means which includes the law penetration to be practiced by people in order to build a majority rule under its hegemony. By integrating the New Codes of law, Netherlands possession in archipelago and its hegemony were expanded to make such a majority rule and kept their group above the line, yet connected to native objects of their occupied indigenous people. This epoch, however, brought into a serious account from Netherlands leaders back then to integrate and to bring the law system in line with that existed in Netherlands after code of law changing in 1 October 1838, [4] in doing so, many Law scholars such as Scholten van Oud-Harleem, Schneiter, and I.F.H. van Nes were appointed to be a member of commission that observed the possibilities of that integration and to make any necessary recommendation in this connection. [4]

After working in East Indies and obtained some necessary data, finally the commission reported a new form of law codification that claimed to be more proper to be applied in East Indies within the framework of:

1. Reglement op de Rechterlijke Organisatie (Court System)

2. Algemene Bepalingen van Wetgeving (Legislation)

3. Burgerlijk Wetboek (civil law book)

4. Wetboek van Koophandel (law of commerce)

5. And other regulation for special cases [5]

Although these settlements were objected to that integration, yet in an actual circumstance Netherlands government tried to exclude a local customary Law (Adatrechts) which is based on local custom in East Indies or Indonesia) into this codification, however, the government arranged it differently by making decrees (ordonnantie/legislatieve akten) through the Indische Staaregeling (East Indies rule of state).

By this policy, many regulations related to the arrangement of indigenous people had been created and registered them under the Staatsblad (state gazette), furthermore within those codification was marriage law that formed gradually along with the civil law code (burgelijk wetboek). In many ways, the Netherlands government was intended to copy the identical law that applied in the Netherlands in a first place, because looked from its constitutional policy amended in 1848[6] it was stated clearly the obvious intention to integrate it in a same line, especially in the marriage system.

The beginning of adopting and penetrating the marriage law into East Indies started after the commission led by Scholten van Oud- Harleem did a research and further also encouraged by the new applied 1848 constitution, even so, this arrangement failed to be concurred in the colonial territory of East Indies and they kept detached between marriage law for European citizen and local indigenous people as well. Thereof according to this, marriage law was divided into kinds according to its personal derivative ethnicity, those different formation are:

1. Marriage law for European citizens and for those who have been acknowledged as a same status like European and thus, subject to the civil law (Burgerlijk Wetboek) of the Netherlands.

2 Marriage law for Muslim people that based on their beliefs

3. Marriage law for those who are not affiliated with either Islam or Christianity subject to their own law or Adat law lke what ever found in Bali in Lombok in which relied on Hinduism

4. Marriage law for those who conduct intermarriage subject to intermarriage law (Reglement van Gemengde huwelijk), which was enacted in 1896 and latter, added with 1904 regulation of intermarriage registration.

5. Marriage law for indigenous Christian that regulated in 1933 to generalize and to harmonize many different means of marriage that existed among Christian member 
from different ethnic.

Those five different regulations were gradually formulated since the beginning of the process of law concordance though it was failed. Rendering this situation, like stated earlier, Netherlands colonial power and existence in the archipelago showed a different harmony in order to keep its authority and influence into being, and this phenomenon is plausible notion in politics and sociology as we called it hegemony.

Hegemony in many ways has been continuing as a social reality that occurred as a reflection of contending situation between two opposite class, strong and weak as also can be more elucidated as the excess relation of what has been called "peripheral society" and centre society.[7] Within the centre culture as portrayed by the Netherlands which had a power, technology, and mean of production and its colonial territory in East Indies as a periphery which was in contrary lack of those elements.

The imposition of Netherlands legal system into different cultures to certain extent had been known as one of the longest process and infliction, thus resulted in the long-lasting existence of its power and authority. This process of legal imposition was made inseparable from its origin country like that of marriage law despite further technical somewhat different in order to cope with the local setting and what is more was designed to extend and maintain their influence and the eradication of local system such as Islamic tradition of legal matrimony, and in some cases, was being into a degraded position. Up to this point, at least, there are facts that rendering the situation of two conflicting societies between the Netherlands and indigenous, and in this case will be subjected on the Islamic tradition that has been living there before the coming of Netherlands imperialism.

\section{Cultural Hegemony By Way of Colonialism}

It is straightly imperative, in many ways, to state something about cultural hegemony before stepping into the subject of this paper related on Netherlands Colonialism in Indonesia, also specifically on that of marriage system. Factually, hegemony is a novel concept, as it is being known in sociology and political science, however the phenomenon was actually has been known and prefigured by scholars in ancient Greek.[8] Thus, hegemony also derived from ancient Greek word that means rule, leader, or guide.

Another understanding of hegemony was showed in $19^{\text {th }}$ century Russians political situation under Lenin and Trotsky, according to both of them hegemony understood as the effort to build a tactical alliance between a working class and other exploited class. This situation gave another meaning, though the term alliance is likely similar to the ancient Greek hegemony, however the subordination and the alliance of domination made a clear situation of hegemony though it was happened in working class level because they own both political advance and social knowledge. This epoch undoubtedly eradicated the provisional government that has lost its influence and authority, and in this case "Bolsheviks" replaced the existing government and formed the Soviet Union. In this sense hegemony is form of domination and subjection of ruling class on the other.

In that, the modern and famous political scientist Antonio Gramsci elaborated those understandings of hegemony from the ancient Greek and Bolsheviks experience to explain the strange and the resistant of certain culture or community, its power and endurance. Gramsci in many ways most likely to be the theorist that closely related to the conception of hegemony. In his concept, hegemony defined as the supremacy and the dominant position of particular class or culture over others, this form of dominance represent the whole aspects and the ability of the ruling class to impose its culture, law, and order to be 
accepted by the subordinate class as it is called by the cultural hegemony. For this ruing class, the possession of power is inevitable and needed as also the process of its maintenance. Thus, power according to Gramsci can be achieved from the dyadic forms of opposition, force and consent, violation and persuasion. Those scheme oppositions cannot be eliminated or applied in a single formation either only coercive or consent. Seemingly, Gramsci elaborated the Machiavellian concept in his Prince, and thus can be perceived as Gramsci's hegemony as many believed this theorist comprehensively described hegemony in a term of power control and cultural domination over others.

Regarding hegemony and cultural domination, it is plausible context to relate social phenomena on western countries colonialism over peripheries, and the same way goes to Netherlands domination over Indonesia (Netherlands East Indies). Colonialism can be easily pointed out as a form of domination in any means, this is can be meant as a domination both with hegemony and without grasping or imposing its order utterly, the first was showed by Netherlands over Indonesia for almost 350 years of domination in which the model of domination rather complex and involved the vast majority of different societies and there are attempts by the colonies to impose a bizarre culture and orders such as imposing law, securing political borders, and marking out territory. Further, regarding the intercultural interaction between colonial government and indigenous people there is such a negotiation through the local rulers and incorporate them into the ruling structures in order to ease the rebellion and massive resistant that could be appeared from that coercive movement. However, the second model is derived from Guha's work on British colonialism in India as he concluded with the domination without hegemony because many aspects were not integrated to the ruling hegemony,[9] in another word this typical domination according to Guha lacking tacit or active subaltern consent, so that there was no hegemony in India.

Whatever of those kinds of colonial hegemony label, the form of domination back then in the period of colonialism played an important role in a process of building a "new world" by a dominance Europeans States, though colonialism has its own explanation, and for this I will not go deeply into the matter, yet in glance. Nineteenth century of European history has filled with a story of colonialism as an effect of the emerging new era that began in industrialization era in British and nearby countries, needles to say, this epoch made a great impact on building the power state and centre of civilization with vast and extensive mode of production $^{\mathrm{i}}$ led them to the expansion of other new world culture as an excess of capitalism which divided the world into labor division of "core and "periphery" as the first is the statepower and the second is the underdeveloped or developed state.Changes of this relation into domination has been, perhaps, strictly related to the notion of European capitalism in searching a competitive new sources and profit. What Hobson wrote about the new imperialism definition seems to be properly rendered this situation:[10]

Differs from the other, first, in substituting for the ambition of a single growing empire the theory and the practice of competing empires, each motivated by similar lusts of political aggrandizement and commercial gain; secondly, in the dominance of financial or investing over mercantile interests.

Thus, the obvious purpose must be supported by the policies and other elements which later organized into a systemic colonial structure like what happened in Netherlands over Indonesia.

Colonialism, albeit it is hard to distinguish from imperialism, is defined as a practice of domination which involves the subjugation of one people to another, taking into account, this process inevitably also described as a cultural hegemony process in later process takes into a symbolic power, the concept launched by Pierre Bourdieu ${ }^{\text {ii }}$ that means the imposition of 
systems of symbolism and meaning upon class or particular social group. In contrary, this form of symbolic violence is not merely accepted by the peasant or dominated group, in that, they take a sudden, sometimes unorganized, and direct rebellion to defend the common interest of the lower class that being imposed by unusual order or way of life, they took several forms as Scott's Weapon of The Weak pointed out such as sabotage, foot dragging, dissimulation, false compliance, slander, arson and so on.[11] Likewise, from those forms as also resistance might take other symbol of resistance from old fashion into a moderate or even subtle polarization. The rebellion such as sabotage, warfare, guerilla, and many other could be said as a form of classic and regular resistant that emerged from a sudden psychological aspect, Padri war fought from 1821 until 1837 between Netherlands and indigenous people of Minangkabau Sumatra, Java war or Diponegoro war between Netherlands and prince Diponegoro and his people and other classic rebellion gave a direct example of the sudden and classic resistance.

In another hand, resistance also takes in a different way and sometimes comes into a subtle explanation. Nonviolence resistance promoted by Gandhi and Martin Luther King rendered a strong principal action of resistance rather than a strategy, this given concept promulgated a way of philosophical and deity aspects, in this case derived from Hinduism for Gandhi and Christianity for King.[12] Nonetheless, in another case a nonviolence strategic or advancing this strategy also can be based on a temporary maneuver to lure rather than a strong foundation like it was practiced by both of them. This particular nonviolent resistance can only be the one of strategies used in a political movement; labor force movement that means could be shifted into a violence movement if it is needed.

Regarding those instances, cultural hegemony and its responsive resistance in a society with a colonialism situation will be more possible to appear in a high tension. What we have seen from the very old age of hegemony to the modern colonialism somewhat has created and even shift a social order. Thus, the particular colonialism occurrence seemingly suffered from this reality in occupied Indonesia by Netherlands, however as mentioned earlier that this kind of hegemony different from that India by British and perhaps African. What is so intriguing that the settlement and infliction of colonizer law, and one of them is the arrangement of marriage law that somehow reflected those hegemony and resistance.

\section{Different Matrimonial System in Netherlands East Indies and its Idea}

After the new constitution amended in 1848 along with a new regulation of colonial government in Netherlands East Indies, the serious intention seemed to be appeared. Ever since, the colonial government was engaged in a delicate conduct of setting and imposing a new set of rule that should be applicable to indigenous people.

The point of core obstacle apparently derived from the complexity of indigenous people consisting of many tribes, religions, and ethnics that obviously each other has a distinct order and rule. Notwithstanding, majority was also exist as the vast growth of Islamic sultanate influence back then in $15^{\text {th }}$ century until the coming of Netherlands. Islamic culture that is believed as either religion or distinct social order has been emerged as a foundation for every single life of people especially in Java Island where the vast majority of Muslim existed. In later, this situation will be another subtle issue for colonial government in ruling its domination.

As it is discussed previously, the adoption of new constitution into a colonial government has become a serious conduct. Initiated by a small committee led by Scholten 
and his member in observing local custom and law, Netherlands government took further engagement in forming a constitution for Netherlands East Indies in September 1854. This constitution likely regulated the basic principal of state where consisted of parliament (volksraad), the executive body (governor general) and the judicial system, also this regulation amended in 1925 named Indische Staatsregeling (Indies State regulation) or IS. With those elements of colonial government, each body would have its own duty to enact a law, decree, and ordinance that regulate every rule including marriage system.

Matrimonial issue in Netherlands East Indies should have a strong relation to a definition and differentiation of citizenship. According to IS and specified in BW (Burgerlijk Wetboek) or civil law, citizenship of Netherlands East Indies is divided into:

1. Netherlands people or other European

2. Indigenous people of East Indies (Bumiputera)

3. Far East People (neither European nor Indigenous)

The social stratification from that division has been regulated into a state law, thus the implication should be happened in the arrangement of different law and social treatment. The first group of European citizen as listed above rendered the upper group that owns a power to gain material resources of social need. Taking this case into a concept of social stratification from Weber,[13] utterly, the European citizen posses three benefits from three kinds of relationship in social stratification, namely:

1. Class power, the access to resources and basic need owned by particular group. The vast and huge material resources of East Indies in first place owned by its people until the Netherlands came and shifted the whole thing, regulate the law, posses the mean of production and resources, so that people of indigenous were suffered and lost their power of owning and accessing this resources. The obvious evidence can be seen from the policy of cultivation system (cultuurstelsel).

2. Social Power, owning a power through a regulation, Europeans gained higher social status and access to a state, and labor power. Though the cultivation system was abolished in 1870, yet the colonial government was still issuing soft policy of trading, commerce, cultivation, and many other aspects. The situation made a European group as a superior and unreachable class because, indeed, the social mobility is rather rigid caused by the lack of people in accessing the social attributes and scarcely distributed valued goods (wealth, means of production, income, good education, and so forth).

3. Political power. By imposing an order and law for all people, colonial government has made a perfect path to gain its purposes through legitimate institution and order by using the state agency and civil service or set of rules. Volksraad (state parliament in Netherlands East Indies) as the regulation machine always produced the colonial government-minded to support its policy and, of course, the cultural hegemony.

Likewise, the matrimonial system basically founded on that differentiation and those differentiations in many ways has been reflected on the different law that applied to each group.

Marriage law differentiation as mentioned in previous chapter divided into five different categories, moreover those categories laid on the different basis and sources, such as Adat law (Adatrecht), Islamic law and so forth, albeit, they are formed and controlled by judicial institutions. Broadly speaking, before outlining the marriage system that approved and being incorporated to the colonial legal system, it is necessarily needed to present the complete provision and differentiation of marriage system in Netherlands East Indies.

First, the IBW (Indische Burgerlijk Wetboek) is originated from NBW (Nederland Burgerlijk Wetboek) that was applied to those of Netherlands people and Europeans. 
However there are several changes and adjustment as it is not imposed entirely, the changes appeared in several articles that viewed as inappropriate to be applied outside the Netherlands. The IBW as it is applied in Netherlands East Indies consists of several articles that regulated the marriage as it written in Book I, Chapter IV until XI and article 26 to 249.

Second, marriage for those who embraced Islam in this situation should follow the Islamic law and subjected to it, as this Islamic law considered as Adat law, this provision is stated in the article 131 IS paragraph (2b) that also insisted lawmaker to respect this distinction thereof this Muslim tradition is permissible. However, as this regulation somewhat being respective and popular, yet the colonial government did not merely escape them from the control, by using the state agency and judicial institution. The state approval on Islamic marriage system marked with the establishment of religious court for Muslim in order to cover all matters regarding Islamic law including marriage, and this institution was made by issuing a royal Decree under No. 24 Staatsblad January 19, 1882.

Third, marriage for those who subjected neither to Islamic law nor to Christianity, and they will have Adat law as their basic law according to each tradition that they belonged. Adat law was a central issue during the period of Netherlands law concordance, the formation of Adat law was created basically by van Vollenhoven in his book entitled "Het Adatrecht van Nederland Indie" (the Adat law of Netherlands East Indies), Vollenhoven defined Adat law as a set of rule and behavioral conduct of far east primitive people that, in some cases, has a liability to be charged and some are not being charge, yet under its traditional way.[14] Each tradition in every region and ethnic defined in a delicate and rather distinct from one to another in a sense of either matrilineal or patrilineal relationship, what is more, one ethnic or perhaps more group in a same region and culture could somehow perform a different practice. Thus, the variety of customary practice of marriage will be something subtle and uncovered area to be regulated, even to be imposed into another legal tradition.

Giving situation was really made a colonial government fully aware of this reality and marriage for those people is subjected and regulated according to their own beliefs, indeed they will never be interfered in this practice, yet the colonial government obliged them to register their marriage which is regulated under a special ordinance.

Fourth, marriage between people from different ethnic and religion as it also called as an intermarriage relationship. Like the different structure of social class that discussed above which also influenced the different submission of law, inevitably this intermarriage reality faced another issue regarding the status of each person engaged in intermarriage. The first attempt was made to enact a regulation on intermarriage which called Gemengde Huwelijk Regeling (GHR) started by a group discussion led by L.W.C van den Berg and H Bakker and supported also by drafts of previous evidence that had ever been made reacting on this issue.[15] Despite the importance of enacting such regulation, there were splitting group that viewed this conduct as not necessarily needed, they believe to the superiority of European law and the importance of the issue is not highly significant.

Ultimately, after being observer of its essence and also supported by Governor General van der Wijck and Minister of colonial affairs Bergsma, Netherlands Government agreed to issue a Royal decree (beslit) on December 29, 1896 entitled "Gemengde Huwelijk Regeling Staatsblad 1898 No. 158". Within this regulation emerged another provision or ordinance explaining legal consequences for intermarriage, they who are committed into this obliged to have their marriage registered and for wife will subjected to her husband legal classification, this provision enacted on June 4, 1904.

Fifth, marriage regulation for indigenous who embraced Christianity. It is no doubt that 
the influence of colonialism goes to the field of religious affair, and indeed this matter is one of the purposes of colonizer to spread their belief, and in this case Christianity. This process began by the coming of European countries such as Spain and Portuguese in Netherlands East Indies in $14^{\text {th }}$ and $15^{\text {th }}$ century,[16] apart from that, after having been occupied and established a strong government along with religious mission, many region mostly outside Java are converted into Christianity such as in Moluccas, Minahasa, Banda, Tapanuli in western Sumatra, and other regions. Despite of their religious affiliation to Christianity, they are likely to engage in their customary law and tradition, including marriage among them.

Because of that, there was a suggestion urged by Governor General De Jonge to compile and impose a general law for them since the matrimonial for Christians is relatively similar, another reason also encouraged to strengthen the influence of European law and further applicability of the codification that might be proper to be imposed in other region. In the beginning of June 1932 Volksraad was received an official ordinance draft of Indigenous Christian marriage (Huwelijk Ordonantie)

Christen Inlanders) from Governor General and a year later this draft was approved. Basic provision of this kind of marriage system was actually indistinguishable from the ordinary system of that European system, except for some parts that derived from local custom. Particular marriage system was compiled and consists of 4 chapter and 78 articles namely:

1. First chapter consists of 50 articles described the essence of marriage

2. Second chapter consists of 17 articles described the provision of a divorce

3. Third chapter consists of 4 articles explained the ignorance of living together as a compulsory

4. Fourth chapter, which is consisting of 7 articles, explained the transitional provisions and other conflicting issue from this ordinance.

Above descriptions, at least for glance, has even captured the social phenomena of the modifying structure of typical colonial hegemony over other group especially when dealing with Islamic group that will be elucidated in the next chapter. Marriage law as a part of civil law was made in order to regulate the relationship among individuals that also has been regulates in a compiled book intended for marriage system, the system as discussed above hierarchically showed the dualism of legal enforcement, indeed the attempt to penetrate an European legal tradition even though it was not clearly visible, and Islamic tradition and local custom or Adat are the only exceptional case where the marriage institutions are remained due to some reasons.

In that, what is more intriguing part regarding this system stratum is the legal submission regulation which is explaining the people affiliation in legal status along with their social strata, as it has been mentioned earlier. According to the new regulation (regeling) of Netherlands East Indies or Indische Staatsregeling (IR) article 131 and furthermore elucidated by the Royal decree on September 1916 No.12 and later amended by Staatsblad (state gazette) No.360 1926,the submission of law can be made by all indigenous people into European Civil Law and by that, they will be subjected to European law, yet this system is not followed by their equal status with those of Europeans. The following pointers are the further explanation of this regulation, namely:

1. Subjection to the European law by Indigenous is strictly unchangeable, for that, someone who has declared his subjection could not be able to undo his decision, and also applied to their descendants. However, it does not change their status of being a lower class member. Along with this position, they will also integrated into a state court of European legal system for all their legal affairs such as marriage for instance. In the 
case of marriage, (which includes divorce, inheritance, and so forth), those people would not be included whether into their Adat or Islamic court (Religie Raad), but they will be in a state court (Landraad). Thereof, this provision is obviously tended to be a political intention, and indeed, colonial government is intended to dominate them through its political power and state agency.

2 Subjection can also be made for several elements in a European civil law that in same cases will be charged into court and legal provisions provided for indigenous.

3. Subjection for particular cases in small extent, for that case will only be solved by European law, such as trade, commerce, and so forth.

4. Automatic subjection for cases that are not provided in Adat law or Islamic law.

Referring to an actual situation before the enactment of state regulation concerning the acknowledgment of marriage system ofIslam and Adat that reflecting the dualism law concept,[17] there was a strong intention of Netherlands government to make legal unification for the whole people under the European law. Seemingly, this concept of unification influenced by liberalists or Universalists who viewed the ideal of law is based on certainty that can only be obtained from compiled law, or specifically they urge European law to be imposed entirely to create a better order.

The Royal decree on the general legislation process (algemene bealingen van wetgeving) which is containing 3 articles and later changed into a law in 1854 (regelingsreglement 1854 article 75), rendered a hidden political intention (rechtspolitiek). Albeit the article 75 of 1854 decree described the dualism of law, the hidden agenda was really apparent from the suggestion of Scholten and van der Vinne to encourage a gradual step through policies of voluntarily submission (vrijwillige onderwerping) and an appropriate statement from government (toepasselijk verklaring).

Under the voluntarily submission, the actual purpose is to provide a remedies through a European legal system which is regulated on state gazette (staatsblad) dated 1926 No.360 as mentioned above, This form of policy is a process of legal enforcement and aimed to lure indigenous people, once they accepted the legal and subjected into it they cannot be able to return to their previous legal tradition. On the other hand, the second policy of appropriate statement is the obvious enforcement by colonial government through law and decree that in specific forced all people to accept a European legal system, although it only issued under particular circumstances.

As I have mentioned in earlier pages, Netherlands hegemony over Netherlands East Indies seems to be a unique example of domination and control. They have a distinct mean to dominate that would be lasted for centuries, dualism of law applied by colonial government somehow, at least, created an appropriate policy regardless of their idea of legal unification. Unlike the British colonialism in India, the Netherlands colonialism in Netherlands East Indies performed in a combination of either coercive and consent means to keep the hegemony in a balance condition, Gramsci's theory of cultural hegemony that insisted the cooperation of either violence and persuasive, perhaps, had been applied to keep the ruling system runs as it expected.

Despite the hegemony in that time went as it was expected, it did not mean there were no conflicts raised by people who really defy the Netherlands colonial government. Undoubtedly, many indigenous are engaged in many conduct of resistance, though its only counted in a soft and rather insignificant. What is essential to be presented here is the act of resistance from a Netherlands scholars who has a strong consciousness and his awareness of respecting cultural varieties.

Cornelis van Vollenhoven, a Dutch legal professor and one of the founders of Local law 
custom or Adatrecht, was best known for his attempt to preserve and defend the existence of a local custom law among native Indies from the colonial government idea of legal unification, many of his works an writings are subjected on the wise suggestion over the Netherlands government to have a thorough foundation before applying such a legal unification for the entire people of Netherlands East Indies.

After being provoked by many of his writings, the Netherlands was being in a difficult situation, though the actual epoch of this unification was not succeeded. Nonetheless, the opponents of van Vollenhoven who are the proponent of unification idea has more in gaining attention of government until the draft of 1914 regarding the European civil law as prepared for the entire colonies, responsively this was unacceptable for van Vollenhoven because it was contradicted the amended regulation of van Idsinga that has been agreed previously,[18] the objection was written by van Vollenhoven under "De Strijd om Het Adatrecht"(the struggle of adat law), in this article he argued for times of inapplicable of that unification, further, he compared the constellation of the legal system in British-India where the system of law is dualistic, while the European law (especially a British common law) is existed, other local customary law such as for Muslim with its Islamic law, Hindu people with their Hinduism are left remained.

The actual situation which is clearly visible from the strong inclination of The Netherlands government to unify the civil law of Europe was, perhaps, stimulated by their successful conduct of criminal law (strafrecht) unification in 1918. Thereof, many attempts were not come to an end, soon after the unification of European criminal law, F.J.H Cowan, the director of Supreme Court Justice in Batavia (recently is Jakarta) promoted another draft of unification on civil law to the government in 1923 to be approved. For Cowan the reason of this unification at least covered in two main points, namely:

1. Adat law mainly is not written in a particular codification and as a result it will give a difficult situation especially for judge to make a legal verdict because it not provides the legal certainty.

2. The varieties of law in one country under one government will cause confusions for many people

In spite of these reasonable arguments, van Vollenhoven did not see any accurate arguments of Cowan, he found the misconception from Cowan's paradigm (as he wrote on Miskenningen van het Adatrecht) of the legal order from each society as he called it "living law". Ultimately, the continuous effort through his writings made a successful effort for van Vollenhoven to suspend Cowan's civil law draft, indeed, the overwhelming structures of the contents numbered 2.200 articles also made this draft inapplicable.

What we can see from this act of response is somewhat offensive conduct by using its authority of being insider, or patronage system. In a brief explanation by Burke in His "history and Social Theory" patronage seems to be a potential element to exchange interests among parties, in this instance is between respective scholars and the government. van Vollenhoven who respectfully famed as a legal scholars in his era owned a symbolic capital of reputation, honor, and prestige. By using this potential achievement, van Vollenhoven was able to create a bargaining effort to pursue his intention. In fact, the unification of legal system as it was a symbol of political power could be shifted in moderate means, so that the continuity of Adat law and Islamic law can be assured. Regarding those explanation, it is also an essential issue to say confidently that marriage system of either Adat or Islamic are able to be incorporated and recognized as distinct social institutions. 


\section{Conclusion}

Cultural hegemony as a social phenomenon that is happening within societies obviously reflected in modern colonial attitudes that began in $18^{\text {th }}$ century. In that, the establishment of hegemony that happened in The Netherlands East Indies was, perhaps, somewhat distinctive. Domination was not only set up in a single manner without communicating opponents of indigenous, even, they imposed systematic law and order as marriage system for instance.

Under the concept of dualism, colonial government has applied a non-violence policy to communicate and incorporate the local people, however they still kept the social stratification that showed the superiority of colonial ruler. Recognizing Adat law and Islamic law as it also included the marriage system, and by giving a legitimate authority through a court system has proofed to be an appropriate policy to keep the domination. However, this domination lasted until the period of Indonesian independence, and imposed into the state regulation, at least until the enactment of 1970 act concerning Islamic marriage.

\section{References}

[1] J. Ball, No Title. Sydney: Ougtershaw PRess, 1982.

[2] J.S Furnivall, Studies in The Social and Economic Development of The Netherlands East Indies IIb, An Introduction to The History of the Netherlands India, 1602-1836,. Rangoon: Studies in The Social and Economic Development of The Netherlands East Indies IIb, An Introduction to The History of the Netherlands India, 1602-1836, (Rangoon, 1934), 16, 1934.

[3] R. Soepomo, Hukum Indonesia Sebelum Peranf Dunia II,( Indonesian legal system before world war II), . jakarta: pradnya paramitha, 1965.

[4] Supomo and Djokosutono, Sejarah Politik Hukum Adat (History of Adat Law policy),. jakarta dan amsterdam, 1954.

[5] W. C. Supriad, Hukum Perkawinan Indonesia dan Belanda, (Indonesian and Netherlands Marriage Law), I. bandung: mandar maju, 2002.

[6] P. Burke, History and Social Theory, Second edi. cambridge: polity press, 2007.

[7] B. Fontana, "Logos and Kratos: Gramsci and the Ancient on Hegemony," pp. 305-326, 2000.

[8] R. Guha, Dominance Without Hegemony, cambridge: Harvard university, 1977.

[9] Jon Elster, Making Sense of Marx, . London: Routdledge, 1975.

[10] J.A Hobson, Imperialism: A Study, (New York: Cosimo Inc, 2005), . new york: cosimo inc, 2005.

[11] James C. Scott, Weapon of The Weak, Everyday Form of Peasant Resistance. London: yale university press, 1985 .

[12] M. J. Nojeim, Gandhi and King, The Power of Nonviolent Resistance,. westport: Praeger, 2004.

[13] P. Saunders, Social Class and Stratification. London: Routledge, 1990.

[14] C. van Vollenhoven, Het Adatercht van Nederlandsch Indie, Volume 1. Leiden: E.J Brill, 1918.

[15] S. Gautama, Segi-Segi Hukum Peraturan Perkawinan Campuran. bandung: Citra Aditya Bhakti, 1996.

[16] K. S. (ed) Jan Sihar Aritonang, A History of Christianity in Indonesia,. Leiden: E.J.Brill, 2008. 
[17] J. van Kan, Uit de Geschidenis van Onze Codificatie,. Batavia: De Unie, 1927.

[18] John Ball, Indonesian Law Commentary and Teaching Materials. Sydney: sydney university press, 1985. 